\title{
緑茶中の降圧活性物質の精製とその性状
}

\author{
伊村 祈年子*, 山 本 武*, 明橋 八 郎** \\ * 大阪市立環境科学研究所 \\ ** 甲子園大学栄盖学部
}

\section{Purification and Characterization of the Hypotensive Substances in Green Tea Leaves}

\author{
Kineko IMURA,* Takeshi YAMAMOTO* and Hachiro AKEHASHI** \\ * Osaka City Institute of Public Health and Environmental Sciences, Osaka, 543 \\ ** Department of Nutrition Koshien University, Takarazuka, 665
}

\begin{abstract}
Nippon Eiyō Shokuryō Gakkkaishi (J. Jpn. Soc. Nutr. Food Sci.) 37, 541 546 (1984)
As a result of a component fractionation of green tea extracts, it was found that ribonucleic acid was a potent principle of the hypotensive activity. However, the nucleic acid fraction retained the activity after alkaline hydrolysis, and further purification of the hydrolysate clarified that the adenylic acid was the most potent one of the active elements.
\end{abstract}

(Received February 18, 1984)

著者らは前報1で，緑茶含有成分を各種の溶蝶を用い て抽出し，その抽出画分をウサギの静脈内に投与し，血 王に及ぼす作用を検討した結果，とくに熱水抽出画分に 強い降圧活性を認めた。さらに本活性は，Sephadex G50 によるゲル满過分析の結果から，260 nm に強い吸収 をるつ高分子画分に存在することか，明らかとなった。 本報では，熱水抽出画分に批ける降圧活性成分をさら に単離精製するとともに，その性状についても娭討を加 えた結果，二，三の知見を得たので報告する。

\section{実 験 方 法}

\section{1. 試菜}

Sephadex G-100: Pharmacia 製, DEAE-セルロー ス: Serva 製, Dowex $1 \times 2$ : Dow Chemical 製, リ ボヌクレフーゼ A，デオキシリボヌクレフーゼ（RNase free) : Worthington Biochem. 製,プロナーゼE：科研 化学製, 透析膜 : Spectram Medical Industries 製, リ ボ核酸（酵母）および 5'ーモノヌクレオチド：Sigma製， その他の試薬はすべて特級を用いた。

\section{2. 試料}

前報 ${ }^{1}$ に準し，煎茶の熱水抽出画分を，30,000 $\times g$ で 遠心分離し，上清を試料とした。

3. ゲル唃過およびイオン交換体

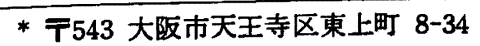

** 干665 宝塚市紅葉ヶ丘 10-1
Sephadex G-100, DEAE セルロース拈よび Dowex $1 \times 2$ を使用し，常法により，膨潤および活性化し，力 ラムに充てんした。

\section{4. 糖の定}

ゲル濾過溶出液は，フェノール硫酸法により $490 \mathrm{~nm}$ で，イオンクロマトクラフィーの溶出液はフンスロン 法2)により $550 \mathrm{~nm}$ の吸光值を測定した。

\section{5. 䁔素処理}

タンパク分解酥素（プロナーゼ）および核酸分解䤃素 （デオキシリボヌクレフーゼ，リボヌクレフーゼ）は， $0.15 \mathrm{M} \mathrm{NaCl}$ に溶解後, $50 \mu \mathrm{g} / \mathrm{ml}$ になるように添加し, $37^{\circ} \mathrm{C}$ で 30 分間作用させた。リボヌクレアーゼは $80^{\circ} \mathrm{C}$ で10分, プロナーゼは $37^{\circ} \mathrm{C} て ゙ 2$ 時間加熱し, 混在する 他の醉素を失活後, 添加した。

6. アルカリ分解 ${ }^{34)}$

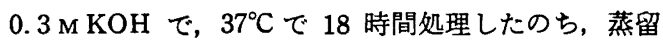
水に対して 24 時間透析した。

\section{7. リンの定是}

Allen $^{5)}$ の方法に準じ，60\% の過塩素酸を用いて，有 機リンを分解したのち，モリブデン青比色法により定量 した。

\section{8. 薄届クロマトグラフィー（TLC)}

DEAE セルロースプレート（Serva 製）を用い, イ ソ酪酸 : アンモニア: 水 $(66: 2: 32)$ の展開溶媒で, 上昇法により展開し，紫外線下で検出した。 


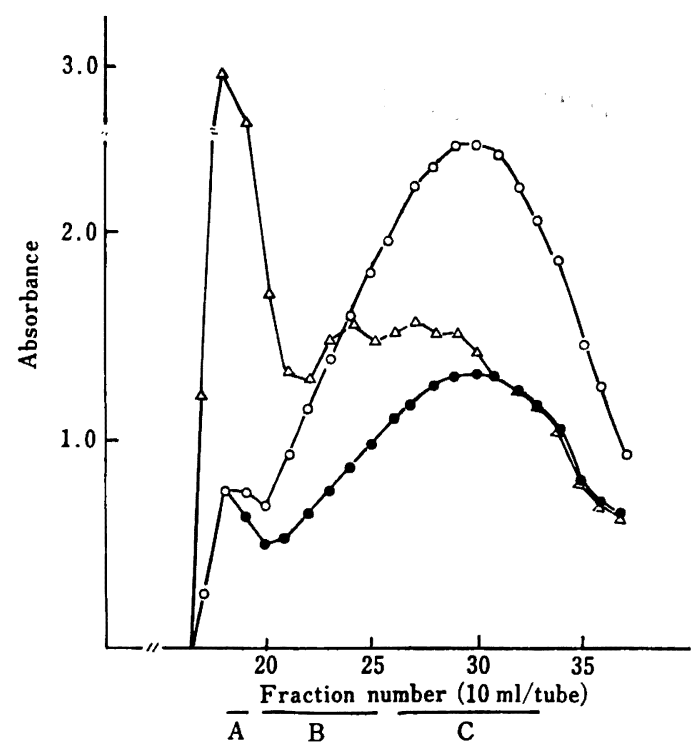

Fig.1. Gel filtration profile of the hot water extract from green tea leaves on Sephadex G-100 column.

○ Absorbance at $260 \mathrm{~nm}$, absorbance at 280 $\mathrm{nm}, \triangle$ absorbance at $490 \mathrm{~nm}$.

The hot water extract solution was centrifuged at $30,000 \times g$ for $30 \mathrm{~min}$. The supernatant $1.5 \mathrm{ml}$ was applied to the column $(2.6 \times 100 \mathrm{~cm})$, and eluted with $0.03 \mathrm{M} \mathrm{NaCl}$ at room temperature. The flow rate was $15 \mathrm{ml} / \mathrm{hr}$.

\section{9. 実験動物之投与方法}

前報1) と同様, 体重約 $2 \mathrm{~kg}$ 前後の白色雄ウサギ 1 群 3 匹を用い,ウレタンで麻酔後左側頸動脈圧を観血的に 測定した。試料は静脈内に投与した。

\section{0. 投与試料}

投与試料は，蒸留水に対して 24 時間透析し，内液 （pH 6 7）を $0.5 \mathrm{ml} / \mathrm{kg}$ となるよう濃度調整し，生理 食塩液として投与した。たたし，イオン交換クロマトグ
Table 1. Phosphorus contents and $\varepsilon(P)$ value at $260 \mathrm{~nm}$ of different fractions obtained from gel filtration on column of Sephadex G-100.

\begin{tabular}{ccccc}
\hline \hline \multirow{2}{*}{$\begin{array}{c}\text { Fraction } \\
(\mathrm{G}-100)\end{array}$} & \multicolumn{2}{c}{ Absorbance* } & \multicolumn{1}{c}{$P$} & $\varepsilon(P)$ \\
\cline { 2 - 3 } & $260 \mathrm{~nm}$ & $280 \mathrm{~nm}$ & $\mu \mathrm{M} / \mathrm{ml}$ & $\varepsilon(P)$ \\
\hline A & 21 & 18 & 0.58 & 36,143 \\
B & 61 & 34 & 5.75 & 10,617 \\
C & 76 & 42 & 9.49 & 8,008 \\
\hline
\end{tabular}

* Measurement was made at $\mathrm{pH} 7.0$.

ラフィーで得たヌクレオチド画分については，透析操作 は行なわない。

\section{実 験 結 果}

\section{1. ゲル滤週}

Sephadex G-100 カラム $(2.6 \times 100 \mathrm{~cm})$ を用い，試料 を吸着させたのち， $0.03 \mathrm{M}$ 塩化ナトリウム溶液で溶出 $(15 \mathrm{ml} / \mathrm{hr})$ し，ゲル濾過を行ない，その結果をFig. 1 に示す。Sephadex G-50 によるゲル滤過で排斥される高 分子画分はさらに糖画分 $\mathrm{A}$ 怙よび $280 \mathrm{~nm} / 260 \mathrm{~nm}$ の吸 光比吕が約 0.55 の值をもつC画分とに分別分離して溶 出された。

1）血圧降下作用 上記溶出画分（A，B，C）の降 圧作用を測定し，Fig. 2 に示す。C画分は， $4.1 \mathrm{mg} / \mathrm{kg}$ の投与で約 $20 \mathrm{mmHg}$ の降圧作用を示したが， A 画分 には，降圧作用が認められなかった。B画分に認められ る降圧作用は一部C画分の混在が考えられた。

2) 降圧画分の紫外部吸収とリンの定量 降圧活性画 分C（40倍希釈 $\mathrm{pH}$ 7)の紫外部吸収スペクトルを Fig. 3 に示し，また，各画分の $260 \mathrm{~nm}$ における吸収の強度 を, Chargaff らの方法"に従い,リン1原子当たりの 吸光係数 $\varepsilon(P)$ として Table 1 に示した。C画分の吸
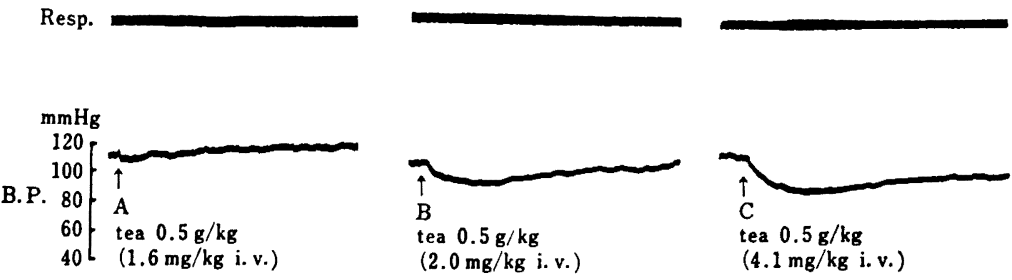

$10 \mathrm{sec}$

Fig. 2. Effects of different fractions obtained from gel filtration on Sephadex G-100 column chromatography on arterial blood pressure in rabbits. 


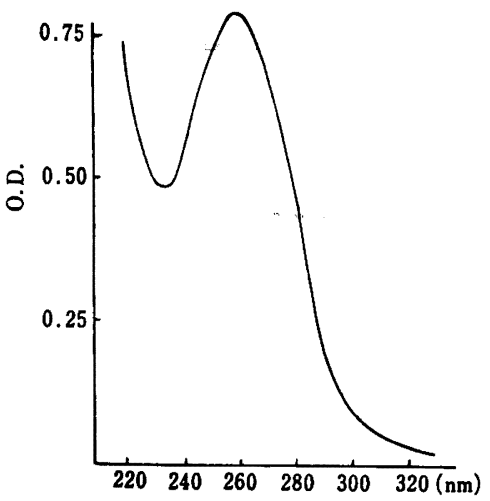

Fig.3. Ultraviolet absorption profile of fraction C of Sephadex G-100 gel chromatography.

収曲線は，260 $\mathrm{nm}$ に吸収極大をるち，230 nmに吸収極 小をむつ核酸に特異的8) な曲線を示し， $\varepsilon(P)$ の値は 8,000であった。

3）酵素処理による降压活性の消失 C 画分に, 核酸 分解醭として，デオキシリボヌクレアーゼおよびリボ ヌクレアーせ，タンパク質分解酳素として，プロナーゼ をそれぞれ作用させたのち，透析し，その内液を投与 し，結果をFig.4に示した。リボヌクレフーぜ処理後の 透析内液の投与では，降圧作用の消失がみられたが，デ オキシリボヌクレアーセ，プロナーセ処理後の内液で は，降圧作用の変化は認められなかった。

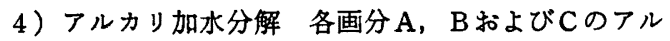
カリ加水分解による紫外部吸収の变化を検討した結果, リボヌクレアーゼの処理により降圧作用の消失がみられ たC画分では，アルカリ加水分解により， $260 \mathrm{~nm}$ の吸 光度が, 76 から 114 と 1.5 倍の増加を示した (Table 2)。 またアルカリ加水分解処理後の透析内液の投与では, リ ボヌクレアーセの処理後の透析内液の投与と同侎降圧作 用の消失が認められた。

\section{DEAE セルロースカラムによる再分画}

以上の結果から降任活性画分 CK, 核酸の存在が予想 されたので，DEAE セルロースカラムにより，核酸成 分の分離を試みた。 $\mathrm{OH}$ 型 DEAE セルロース9ははらら

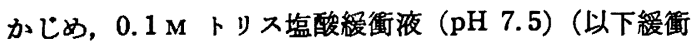
液) 飞哥濁，平衡化したカラム $(1.2 \times 15 \mathrm{~cm})$ K, C 画 分 $2 \mathrm{ml}$ を吸着させた。溶出は同楥衝液中の食塩濃度 $0.1 \mathrm{M} \rightarrow 0.8 \mathrm{M}$ の連続的濃度こう配法によった。その結 果酸性糖画分 I および $0.5 \mathrm{M}$ 付近の食塩で溶出される 核酸画分 IIを得た（Fig. 5)。

1）血压降下作用 酸性糖画分 I および核酸画分 II 投与し降代作用を測定したところ，核酸画分Iに降圧作 用が認められ, 精画分 I には降任作用が認められなかっ た。
Table 2. Hyperchromic effect of alkaline hydrolysis.

\begin{tabular}{ccc}
\hline \multirow{2}{*}{ Fraction* } & \multicolumn{2}{c}{ Changes of absorbance at $260 \mathrm{~nm}$} \\
\cline { 2 - 3 } & nontreatment & alkaline hydrolysis \\
\hline $\mathrm{A}$ & $21(1.0)$ & $25(1.19)$ \\
$\mathrm{B}$ & $61(1.0)$ & $82(1.34)$ \\
$\mathrm{C}$ & $76(1.0)$ & $114(1.5)$ \\
\hline
\end{tabular}

* Gel filtration on Sephadex G-100 column.

Table 3. Ratios of $A_{250}$ versus $A_{260}$ and $A_{280}$ versus $A_{260}$ various nucleotide fractions.

\begin{tabular}{ccc}
\hline \hline Fraction & $250 \mathrm{~nm} / 260 \mathrm{~nm}^{*}$ & $280 \mathrm{~nm} / 260 \mathrm{~nm}^{*}$ \\
\hline $\mathrm{F}-1$ & 0.476 & 2.0 \\
$\mathrm{~F}-2$ & 0.81 & 0.39 \\
$\mathrm{~F}-3$ & 0.94 & 0.69 \\
$\mathrm{~F}-4$ & 0.76 & 0.40 \\
\hline
\end{tabular}

\begin{tabular}{ccc}
\hline $\begin{array}{c}\text { Authentic } \\
\text { nucleotide }\end{array}$ & $250 \mathrm{~nm} / 260 \mathrm{~nm} *$ & $280 \mathrm{~nm} / 260 \mathrm{~nm} *$ \\
\hline CMP & $0.45-0.48$ & $1.80-2.10$ \\
AMP & 0.85 & 0.22 \\
GMP & 1.02 & 0.68 \\
UMP & $0.74-0.80$ & $0.28-0.38$ \\
\hline
\end{tabular}

* Measurement was made at $\mathrm{pH} 2.0$.

2）薄層クロマトクラフィーによる画分 Iの同定上 記の操作で得た核酸画分 II を同定するため，同画分をつ ルカリまたは、リボヌクレフーゼで分解し，その分解物 について薄層クロマトグラフィーを行なった。また醭母 リボ核酸のアルカリ分解物および $5^{\prime}$-モノスクレオチド の標品もともに展開した。その結果 Fig.6 に示すよう に，画分 Iの分解物は，醉母リボ核酸のアルカリ分解に よる 4 種の $2^{\prime}\left(3^{\prime}\right)$-モノヌクレオチドと一致する $R f$ 值 が認められた。

このことから画分 Iの主成分は、リボ核酸であると推 定された。

\section{3. イオン交換樹脂による画分 II の構成成分の分離}

画分 IIは，リボ核酸が主成分であろらと考えられたこ とから，さらに画分構成成分を分画し，各画分につ いて降圧作用を測定するため，大沢ら ${ }^{103}$ の方法に準じ て, Dowex $1 \times 2$ キ酸型カラム $(0.8 \times 30 \mathrm{~cm})$ によるカ ラムクロマトクラフィーを行なった。画分而は，アルカ リ分解し, 過塩素酸で中和, その上澄液 $\left(E_{260} / \mathrm{ml}=75\right) 4$ $\mathrm{ml}$ を吸着させた。溶出は, キ酸濃度 $0 \rightarrow 4 \mathrm{~N}$ の連続濃度 


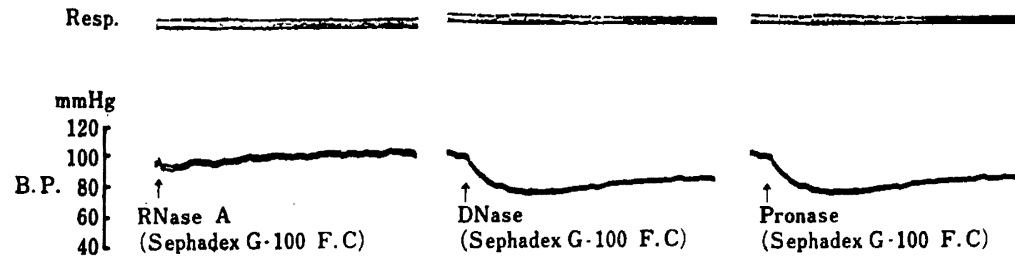

$10 \mathrm{sec}$

Fig. 4. Effect of enzyme treatments on blood pressure depression activity.

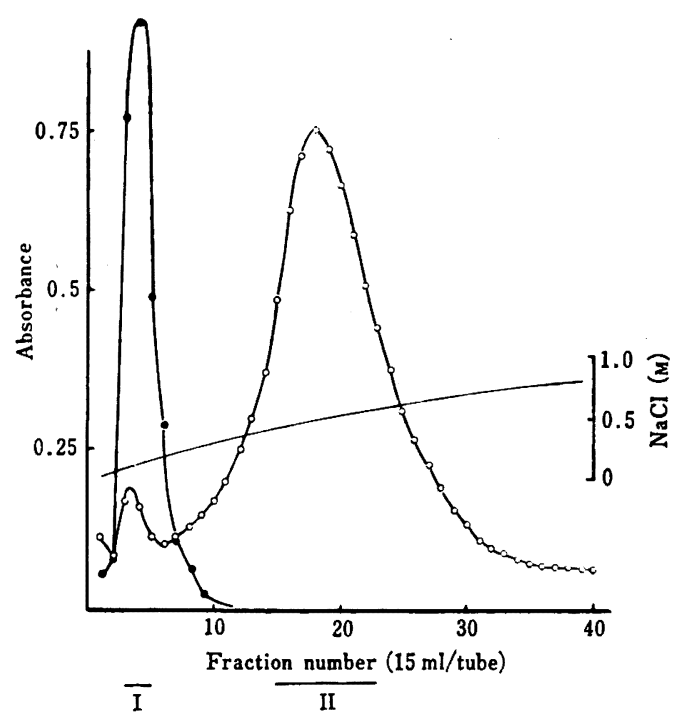

Fig.5. Elution profile of the fraction $\mathrm{C}$ on DEAE cellulose column chromatography.

Absorbance at $260 \mathrm{~nm}$, absorbance at 550 $\mathrm{nm}$.

The fraction C obtained from Sephadex G-100 chromatography was applied to the column (1.2 $\times 15 \mathrm{~cm}$ ), equilibrated with $0.1 \mathrm{M}$ Tris buffer $(\mathrm{pH}$ 7.5) and eluted with a linear $\mathrm{NaCl}$ gradient from $0.1 \mathrm{M} \mathrm{NaCl}$ to $0.8 \mathrm{M}$ in the same buffer at room temperature. The flow rate was $24 \mathrm{ml} / \mathrm{hr}$.

こら配法により行ない，その結果をFig.7に示した。最 初に溶出されるシチジル酸の紫外部吸収は, $280 \mathrm{~nm} / 260$ $\mathrm{nm}=2$ であることから同定された。また各溶出画分の 同定は，外部吸収係数 ${ }^{11} に よ り$ 行なった（Table 3)。

血圧降下作用 : 上記の各画分をロータリーエパポレー タによりギ酸をとばすとともに濃縮し投与したところ, アデニル酸画分では, $0.23 \mathrm{mg} / \mathrm{kg}$ の投与で約 $28 \mathrm{mmHg}$, $0.45 \mathrm{mg} / \mathrm{kg}$ の投与で約 $34 \mathrm{mmHg}, 0.9 \mathrm{mg} / \mathrm{kg}$ の投与 で約 $42 \mathrm{mmHg}$ の降圧作用が認められた（Fig. 8)。し かし,シチジル酸，グアニル酸, ウリジル酸の各画分の投

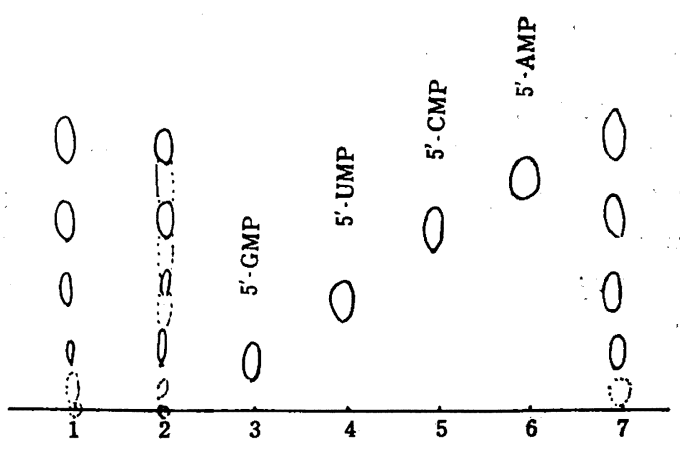

Fig.6. Thin layer chromatogram of RNase digests and alkaline hydrolysates.

Absorbent : DEAE-cellulose, solvent : iso-BuCO$\mathrm{OH}, \mathrm{NH}_{3}, \mathrm{H}_{2} \mathrm{O}$ (66:2:32).

1, Alkaline hydrolysates of tea RNA; 2, enzymatic digests of tea RNA by RNase $A ; 3 \sim 6$, authentic nucleotides; 7 , alkaline hydrolysates of yeast RNA.

与においては，降圧作用が認められなかった (Fig.9)。

$$
\text { 考察 }
$$

前報”に拈いて，緑茶熱水抽出画分における降圧作用 は Sephadex G-50 によるゲル滤過により排斥される高 分子画分に溶出され，その主要な降王活性の本体は，有 機成分であるとの示唆を得た。そこで今回は, Sephadex G-100 によるゲル滤過およびイオン交換クロマトグラフ イーによる降王成分の分離, 精製を試みるとともに, 降 圧成分の性状についても検討した。Sephadex G-100 に よるゲル滤過では，核酸に特有な紫外部吸収スベクトル を示す画分 C(Fig.3) に降圧活性が認められ，260 nm に护ける吸収の强度 $\varepsilon(P)$ は 8,000であった(Table 1)。 $\varepsilon(P)$ の值は, 一般にデオキシリボ核酸では $6,000 \sim$ 8,000, リボ核酸では 7,000 10,000 であること ${ }^{12), ~ ま ~}$ 


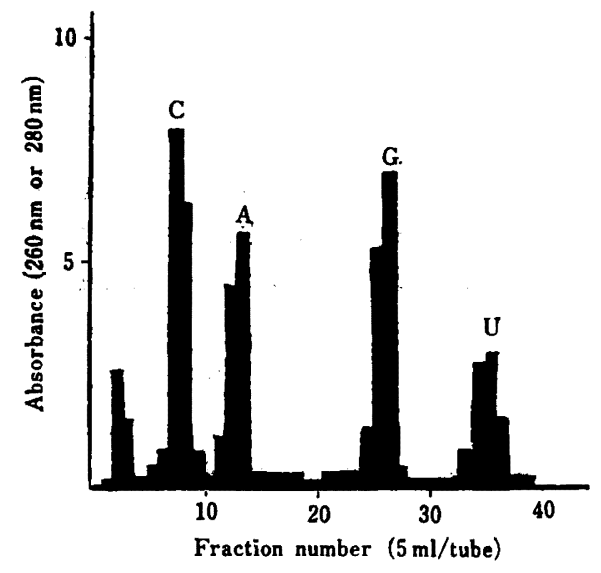

Fig.7. Separation of individual mononucleotides of the tea RNA alkaline hydrolysate on Dowex-1 column chromatography.

The fraction II (tea RNA) obtained from DEAEcellulose chromatography was applied to the column (formate form $0.8 \times 30 \mathrm{~cm}$ ). The alkaline hydrolysate was the "formic acid system" (accoding to Hurlbert et al. $\left.{ }^{22}\right)$. The flow rate was $12 \mathrm{ml} / \mathrm{hr}$.

C, cytidylic acid; A, adenylic acid; G, guanylic acid; U, uridylic acid.
た，画分Cをアルカリ加水分解することにより，260 nm に批るる吸光度は約 1.5 倍に增加し (Table 2), この現 象はリホホ核酸のフルカリ分解による深色奻果 ${ }^{13)}$ として知 られていること，また，画分Cのリボヌクレフーぜ処理 液ならびにアルカリ分解液の透析内液での投与におい て，降圧活性の消失がみられたことなとから，降圧活性 画分Cにはリホ核酸を含有すること，またその䡋度 は，核酸のリンの含量を約 $9 \%^{14)}$ およびリホ核酸 $1 \mu \mathrm{g} /$ $\mathrm{ml}$ の $\mathrm{OD}_{260 \mathrm{~nm}}=0.022^{13)}$ として算出すれば, Table 1 に示した画分Cのリン含量と $260 \mathrm{~nm}$ の吸光値から, 約 $0.3 \%$ と推定された。そこで，さらに画分 Cを DEAE セルロースカラムにより再分画し (Fig.5)，核酸成分を 分画して降圧作用を測定した結果，核酸画分（画分 II） に降圧作用が認められた。この核酸画分は、リボヌクレ アーゼまたはアルカリ加本分解後薄層クロマトクラフィ 一により，4種の $2^{\prime}\left(3^{\prime}\right)$-モノヌクレオチドに加水分解 されていることが明らかとなり（Fig.6)，主成分はりボ

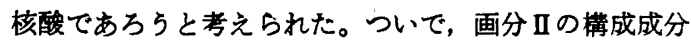
をイオン交換樹脂 Dowex 1 によるカラムクロマトクラ フィーで分崔し，得た各ヌクレオチド画分の降圧作用を 測定したところ，降圧活性の中心はフデニル酸画分にあ ることが判明した。この活性は，用量の增加とともにそ の降圧作用を增加した。

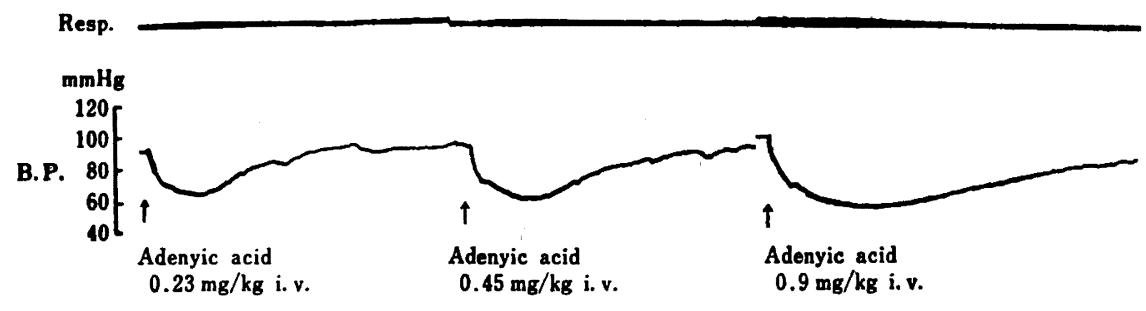

10 sec بسس

Fig. 8. Effects of adenylic acid fraction obtained from ion-exchange on Dowex-1 column chromatography on arterial blood pressure in rabbits.

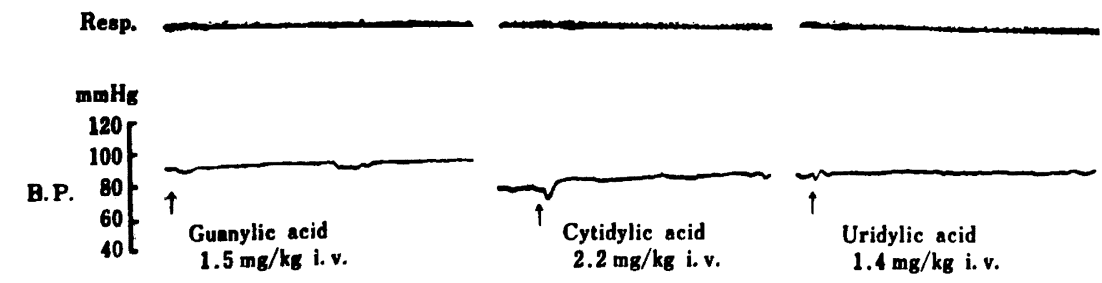

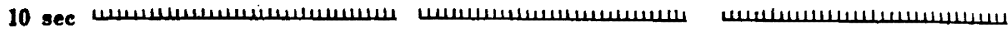

Fig.9. Effects of various nucleotide fractions obtained from ion-exchange on Dowex-1 column chromatography on arterial blood pressure in rabbits. 
すでに述べたよらに，Sephadex G-100 によるゲル渚 過で得た降压活性画分 C（約 $20 \mathrm{mmHg}$ (Fig.2)）は， 約 $0.3 \%$ の核酸を含有し，核酸としての投与量は，約 $1.5 \mathrm{mg} / \mathrm{kg}$ (体重) となる。さらにアデニル酸としての 投与量は，核酸中のアデニル酸のモル比から，約 0.38 $\mathrm{mg} / \mathrm{kg}$ (体重) と計算される。そこで，イオン交換樹脂 で分離したフデニル酸画分の投与量 (Fig.8) とC画分中 のアデニル酸としての投与量とを対比させその降圧作用 を検討すると、アデニル酸としての活性作用は，ほぼ同 程度であることが認められた。これらの実験事実から， 核酸として投与したアデニル酸量と単一のアデニル酸の 有効投与量とは，同価であると考えられる。

緑茶の熱水抽出画分に拈ける降圧作用は，イ邓の静脈 内の投与 ${ }^{15)}$ ，本態性高血圧の疾患モデルとして広く用 いられている高血正自然発症ラット $(\mathrm{SHR})^{16)}$ の経口投 与実験 ${ }^{17)}$ においても降圧作用を認めたことから，ウサギ に特異的な作用ではないと考光られる。

一方，アデノシン物質（アデノシンやフデニル酸な ど）は，血管平滑筋の弛かん作用による血管扗張物質 ${ }^{18)}$ として知られているが，近年細胞内の cyclic AMP が 広く細胞機能の調節に関与し，各種のホルモン作用を媒 介し，ホルモン刺激のメッセンジャーとして働くたけけで なく，中权神経の機能調節にも関与している可能性が示 唆19) 21)され，さらに脳の神経伝達におけるアデノシン 物質の生理活性への関心が急速に高まっている。これら の知見と合わせて考えると, 緑茶中の核酸として投与し た有効成分す同様の作用機構によるのかるしれない。

また, 高血圧自然発症ラット (SHR) の大動脈では, cyclic AMP のレベルの低下が認められており ${ }^{23)}$ ，フデ ノシン物質と血圧との関連については, 今後の重要な課 題であると考えられる。

要 約

緑茶の熱水抽出画分に打ける降圧活性成分を, さらに 分離精製するとともに，その本体について性状の検討を 行なった。

1) Sephadex G-100によるゲル濾過では，260 nm 付 近に吸収極大をもち, $230 \mathrm{~nm}$ 付近に吸収極小をむつ C 画分に降圧作用が認められた。

2) C画分のリボヌクレフーゼ，または，アルカリ処 理後の透析内液では降王活性が認められなかった。

3) DEAE セルニースカラムによる分画では、リボ 核酸画分に降圧活性を認めた。

4）リボ核酸画分のアルカリ分解液を, Dowex 1 カ ラムを用いて，モノヌクレオチドに分画して投与したと ころ，アデニル酸画分に降圧活性を認め，クフニル酸， ウリジル酸、シチジル酸画分には認められなかった。ア
デニル酸画分は， $0.23 \mathrm{mg} / \mathrm{kg}$ (体重)の投与で約 28 $\mathrm{mmHg}, 0.9 \mathrm{mg} / \mathrm{kg}$ (体重) の投与で約 $42 \mathrm{mmHg}$ の降 圧作用を示した。

稿を終えるにあたり，贵重な示唆，ご指導を賜わった 香川医科大学安部陽一教授に愿くお礼申しあげます。ま た，終始ご援助をいただきました大阪市立環境科学研究 所食品栄養課佐々木清司課長, 衛生化学課山田明男課 長，大垣寿美子研究員に深く感謝いたします。

本論文の要旨は, 第 38 回日本食品衛生学会学術講演 会（昭和54年11月，仙台）において発表した。

\section{文献}

1) 伊村新年子, 明橋八郎 : 栄食誌, 37, 535 (1985)

2) Roe, J.H. : J. Biol. Chem., 212, 335 (1955)

3) Marrian, D.H., Spicer, V.L., Balis, M.E. and Brown, G.B. : J. Biol. Chem., 189, 533 (1951)

4) Davidson, J.N. and Smellie, R.M.S. : Biochem. J., 52, 594 (1952)

5) Allen, R.J.L. : Biochem. J., 34, 858 (1940)

6) 满田久輝：実験栄盖化学, 75 (1961)，いずみ毒 房 (京都)

7) Chargaff, E., Zamenhof, S. : J. Biol. Chem., 173, 327 (1948)

8）江上不二夫編 : 蛋白及び核蛋白質，243 (1951), 共立出版（東京）

9) Otaka, E., Osawa, S., Oota, Y., Ishihama, A. and Mitsui, H. : Biochim. Biophys. Acta, 55, 310 (1962)

10）大沢省三, 堀田康雄 : 蛋白質 核酸 醅素, 11, 524 (1966)

11) 日本化学会編：実験化学講座 23，292 (1957), 丸善 (東京)

12) 日本化学会編：実験化学講座 23,250 (1957), 丸 善 (東京)

13）水野重樹：生物化学実験法，69（1969), 東京大学 出版会 (東京)

14）江上不二夫 : 蛋白及び核蛋白質, 225 (1951)，共 立出版 (東京)

15) 伊村新年子, 山本 武, 明橋八郎 : (未発表)

16) Okamoto, K. and Aoki, K. : Jpn. Circul. J., 27, 282 (1963)

17）伊村祈年子, 大垣寿美子, 山本 武：日本食品衛 生学会第43回学衍講演会, 講演要旨集

18) 原 主郎: 薬理学入門, 161 (1956), 南山堂 (東 京)

19）垣内史郎：蛋白質 核酸 酵素, 12，324（1967）

20）垣内史郎：蛋白質核酸 醅素, 14, 336 (1969)

21）黒田洋一郎: 蛋白質 核酸 醅素, 26, 28 (1981)

22) Hurlbert, R.B., Schmitz, H., Brumm, A.F. and Potter, Vam R.: J. Biol. Chem., 209, 23 (1954)

23) Amer, M.S. : Science, 179, 807 (1973)

（昭和 59 年 2 月 18 日受理） 